\title{
The Professional and Economic Development of Individuals with Disabilities in the Hospitality Sector with a Focus on the Importance of Training and Skill Enhancement at all levels: Hungarian Perspective
}

\author{
Ambuj Sharma ${ }^{1}$, Martin Zsarnoczky² and Anna Dunay ${ }^{3}$ \\ ${ }^{1}$ Ambuj Sharma, Szent Istvan University, Hungary \\ ${ }^{2}$ Martin Zsarnoczky, Kodolanyi Janos University of Applied Science, Hungary \\ ${ }^{3}$ Anna Dunay, Szent Istvan University, Hungary
}

\begin{abstract}
The paper provides an in-depth study on one of the significant management interventions within firms regarding the issues of training and skills development to create an inclusive workplace for the people with disabilities. This study aims to explore attitudes of employers toward training employees with disabilities in the hospitality sector in Hungary. Another objective of this study is to fill the gap with a focus on two more specifications: aesthetic labor as a key selection tool of hotel recruiters, and to gather information on the understanding of employers on providing reasonable accommodations for employees with disabilities. Survey method was adopted as the main data collection instrument. Primary data was collected majorly via paper-and-pencil administration and web based survey (google forms). 859 questionnaires distributed of which 212 questionnaires were returned, indicating a response rate of $24.6 \%$, but only 174 questionnaires were used for the analysis. The one of the results highlighted was the importance of providing training on comprehensive work-related skills (soft, technical and social) which are considered crucial for people with disabilities to sustain in the labour market. This study also add new empirical insights into existing international literature on the importance of employees selection on the basis of their physical attributes, and the perception of employers on the range of workplace changes to accommodate employees with different forms of disabilities and their degree of severity. In the final section, the article offers recommendations for future
\end{abstract}


research which if adopted could lead to professional advancement in the lives of people with disabilities.

Keywords: aesthetic labor, attitudes, employees with disabilities, reasonable accommodation, soft skills.

\section{Introduction}

To participate and sustain in the labor market, it is quite essential for individuals to have requisite qualifications and appropriate skills. Acknowledging this reality, it is crucial for employees to professionally upgrade themselves from time to time and adapt their skills to changing technological and economical job market scenarios; in this people with disabilities (PWD) is no exception. Employment data on people with disabilities are hard to come by in almost every country within European Union. In the EU 28 member states, the employment rate of people aged 15 to 64 years with disability was documented at $47.3 \%$ and highest employment rate was reported for people with disabilities in Sweden, and lowest in Hungary (Eurostat 2014). In Visegrád Group (V4), which includes Hungary, Slovakia, the Czech Republic and Poland, the employment rate of persons with disabilities in Hungary, aged 15-64 was $23.7 \%$. On the contrary, employment rate above 35\% was recorded in Czech Republic, as shown in table 1.

Tab. 1: Employment rate in the V4 countries, by disability status, 2011 (people aged 1564).

\begin{tabular}{|c|c|c|c|}
\hline V4 countries & $\begin{array}{c}\text { Persons with disabilities } \\
\text { (in \%) }\end{array}$ & $\begin{array}{c}\text { Persons with no } \\
\text { disability (in \%) }\end{array}$ & $\begin{array}{c}\text { Gap (in percentage } \\
\text { points) }\end{array}$ \\
\hline Czech Republic & 38.6 & 68.5 & -29.9 \\
\hline Hungary & 23.7 & 61.1 & -37.4 \\
\hline Poland & 33.9 & 63.9 & -30.0 \\
\hline Slovakia & 31.9 & 62.6 & -30.7 \\
\hline
\end{tabular}

Source: EUROSTATS (2014).

According to the data published by the Hungarian Central Statistical Office (In Hungarian language Központi Statisztikai Hivatal (KSH)), almost half a million individual with disabilities reported in the country (KSH 2011), but the same population is expected to reach 1 million by 2021 (RHS 2018 citing Berend 2018). In most of the areas in Hungary, low unemployment rate was recorded and Hungary being one of the fastest-growing economies in Europe, there is shortage of labour (Alderman and Santora 2019). There were an estimated 140,086 people of working age $(19-64)$ with disabilities who were employed, but with the participation of women with disabilities $(72,403)$ in labour market being higher than the men with disabilities $(67,683)$ (KSH 2016). Table 2, shows in-depth labour market scenario of people with disabilities (population aged $19-64$ years) in Hungary. The labor shortage has grown acute as thousands of young Hungarians migrated to western European cities in recent years for better-paying jobs. 
Addressing macro-economic trends in Hungary, the gross domestic product of Hungary rose by $2.0 \%$ in 2016 compared to a year earlier, with which Hungary is in the middle of the ranking of EU member countries (KSH 2017). It has been recently reported that Hungary economic situation could face "a major macroeconomic constraint" as more than 80,000 positions are vacant in the construction, manufacturing, retail and tourism sectors (Alderman and Santora 2019). Specific and accurate data on the industry wise employment situation are harder to find in Hungarian context. According to data of 2011 of Hungarian Central Statistical Office (KSH), the highest participation was reported for manufacturing industry with 15,241 people with disabilities within working age population. Surprisingly, food and accommodation industry reported total participation of 2,416 PWD which reported one of the lowest employment engagement by people with disabilities (KSH 2011).

Tab. 2: Main Labour Market Indicators of population of people with disabilities (Aged 19-64 years, \%) in Hungary.

\begin{tabular}{|c|c|c|c|c|c|}
\hline \multicolumn{4}{|c|}{ PWD active in the labour market } & \multicolumn{2}{|c|}{140,086} \\
\hline \multicolumn{4}{|c|}{ Men with disabilities active in the labour market } & \multicolumn{2}{|c|}{72,403} \\
\hline \multicolumn{4}{|c|}{ Women with disabilities active in the labour market } & \multicolumn{2}{|c|}{67,683} \\
\hline & $\begin{array}{c}\text { Employment rate } \\
(\%)\end{array}$ & $\begin{array}{c}\text { Unemployment } \\
\text { rate }(\%)\end{array}$ & $\begin{array}{l}\text { Participation } \\
\text { rate }(\%)\end{array}$ & $\begin{array}{c}\text { Inactivity rate } \\
(\%)\end{array}$ \\
\hline \multicolumn{2}{|c|}{ Total } & 20.8 & 18 & 25.4 & 74.6 \\
\hline \multicolumn{2}{|c|}{ Males (\%) } & 21.6 & 19.4 & 26.8 & 73.2 \\
\hline \multicolumn{2}{|c|}{ Females (\%) } & 20.2 & 16.6 & 24.2 & 75.8 \\
\hline \multirow[b]{2}{*}{$\begin{array}{l}\text { Region } \\
\text { wise } \\
\text { statistics }\end{array}$} & Highest (\%) & Baranya (28.1) & Somogyi (30.6) & Baranya (31.6) & $\begin{array}{l}\text { Nógrádand } \\
\text { Zala (82.2) }\end{array}$ \\
\hline & Lowest (\%) & Nógrád (13.5) & $\begin{array}{c}\text { Győr-Moson-Sopron } \\
\text { (4.1) }\end{array}$ & $\begin{array}{c}\text { Nógrádand Zala } \\
\text { (17.8) }\end{array}$ & Vas (60.0) \\
\hline
\end{tabular}

Source: KSH (2016).

The highly competitive hospitality industry requires a skillful workforce to remain functional and one of the main problems is to find skilled manpower. Budapest city with a fascinating history and cultural heritage serves as an attraction for visitors from around the world. In such labor shortage scenario in Hungary, individuals with disabilities could represent an important under-utilized workforce source for hospitality sector. In connection with country's economic performance as highlighted in KSH report titled Hungary 2016, "486 billion forints of gross value added were produced at current prices in accommodation and food service activities based on data for 2015, 1.7\% of the total performance of the national economy" (KSH 2017 p.17).

Training and skill development programs are important for the professional growth of individuals with disabilities and it is rightfully important for them to have equal access to various strata of the labor market. People with disabilities when integrating 
into the job market face various professional barriers such as, non-availability of professional and managerial opportunities, qualification constraints, high level of economic imbalances, attitudes of co-workers with no disabilities and disability-job compatibility requisites. Simply hiring individuals with disabilities is not enough, but the management needs to provide ample training and skills development recourses to world's largest minority to be competitive and sustainable in today's economic fluctuating trends. The rationale behind training and skill development endeavors is the identification of the key gaps in corporate strategies, and to provide material and program structure explicitly suited for individuals with diverse bodily and intellectual abilities.

The objective of this article is alleviating the long term problems related to the professional inclusion of individuals with disabilities in terms training and skill development avenues available to them to achieve their professional and personal goals. Following article contains topic-specific content on disability, training, skills (social, communication and technical) and cost related to training and skill development constraints. Therefore, the overall aim of this research is to evaluate the attitudes of employers toward employees with disabilities with regards to training and skills development. Two more objectives to ascertain: to what extent employers in hospitality industry in the city of Budapest are ready to make/would make reasonable accommodations for employees with disabilities, and to explore if employers perceive that aesthetic and self-presentation skills are pre-requisite requirement to apply for a position in hospitality industry. Above section has already provided background information on Hungarian and EU labor market participation statistics of people with disabilities. Authors have also discussed the purpose and objectives of study which led to a call for confirmatory approach to understand the employers attitudes in hospitality sector in Hungary. In below sections, research methodology is explained, as also quantitative research, the different procedures of data collection, validity and reliability analysis, and achieved response rate. The empirical part is exhibited in result section, which consists of the analysis and representation of data with furnishing of the quantitative outcomes, and comparison with international literature based on results interpreted from this research study. Finally in the last section, authors include the conclusion of the study with recommendations.

\section{Methodology}

In the study the attitudes of employers (for example, chef, owners, supervisor, manager, etc.) about training and skill development issues in the hospitality sector with regards to employees with disabilities will be examined. In order to collect appropriate primary data, the researchers decided to go ahead with business survey (direct method approach). Kothari (2004 p. 95) in his book titled, Research Methodology: Methods \& Techniques, refers surveys to the "method of securing information concerning a phenomen under study from all or a selected number of respondents of the concerned 
universe. In a survey, the investigator examines those phenomena which exist in the universe independent of his action". Originally, the employer attitude assessment questionnaire developed by $\mathrm{Chi}$ and $\mathrm{Qu}$ (2003), and same tested scale was again revised and utilized by Paez (2010). Both studies were conducted in the USA but in different geographical locations. The instrument, re-designed and re-structured again by the authors included most of the questions from both instruments and in addition to the attitude measurement and knowledge about the concept of disability, the scale also included a demographic section. Email was sent to the authors of both studies to obtain approval to adopt their questionnaires for this current study. Below table 3 provide brief overview of previous instrument of Paez (2010), and revised instrument for the better understanding.

Tab. 3: Brief description of data collection instrument (original and final version).

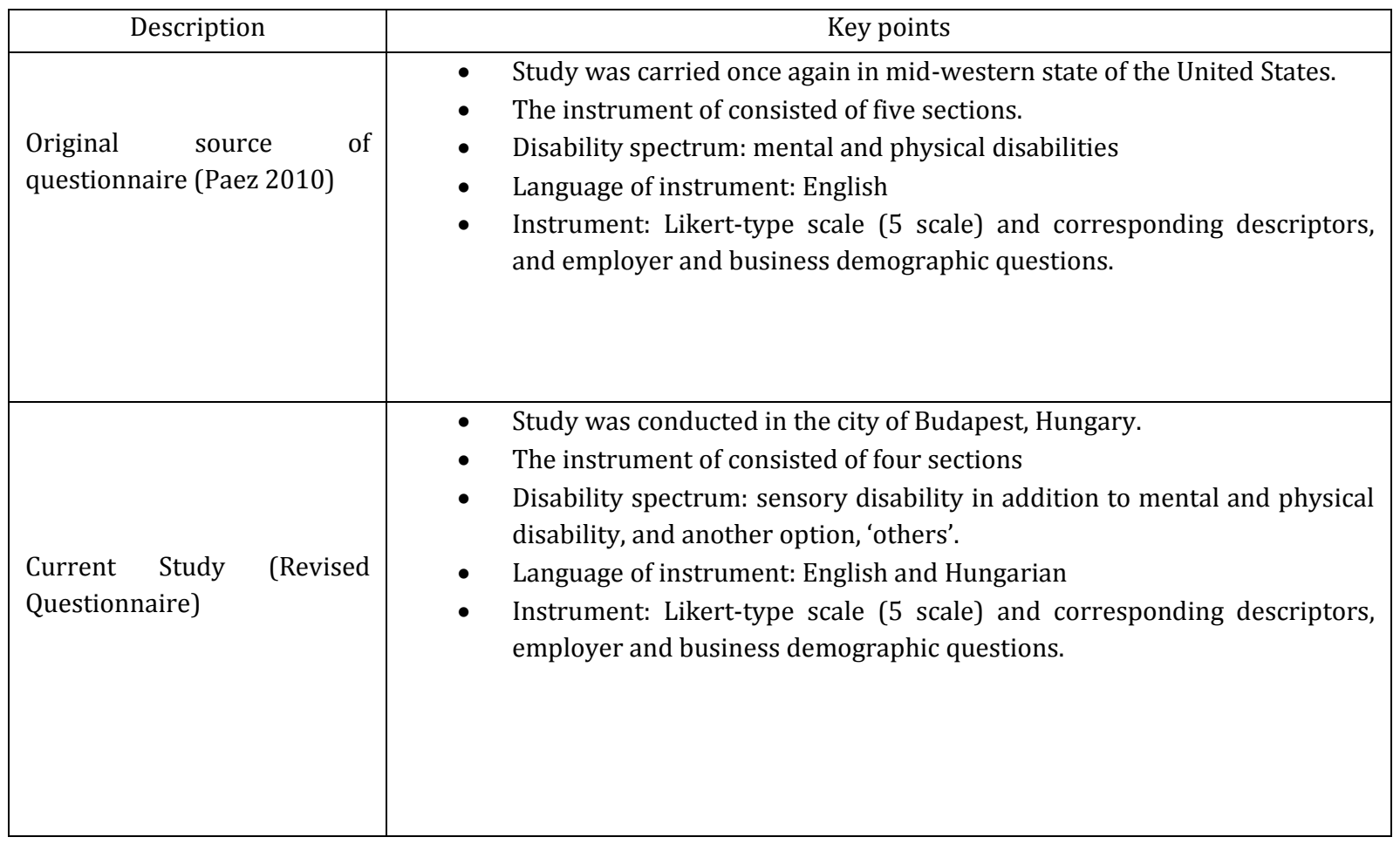

Source: Authors own work.

The revised and final instrument consists of four sections, section 1: Personal beliefs, perception and attitudes scale (Q1 - Q35); section 2: Knowledge about disabilities (Q36, Q37, Q38); section 3: Tell us about your organisation (Q39-Q46); and finally section 4: Personal details (Q47 - Q53). Section 1 incorporates a 5-point Likert-style scale ranging from 1 (strongly disagree) to 5 (strongly agree), but authors included some negatively worded questions in the questionnaire (reversely coded, 1 (strongly agreed) to 5 (strongly disagree). From a large pool of items from all sections; only 17 items from section 1 was retained for the analysis in this article as outlined in the table number 5 to address the first objective pertaining to training and skill development scenarios. Sekaran (2003) also recommends inclusion of negatively worded questions in the research, "include some negatively worded questions as well, so the tendency in 
respondents to mechanically circle the points toward one end of the scale is minimized" (p. 240).

The instrument was originally written in English and so had to be translated to Hungarian language. The official language of Hungary being Hungarian, entire questionnaire including supporting letters were translated to that language by a certified bilingual translator, to ensure accuracy and quality of translated work. Hungarian is the largest of the Uralic languages and is very different from English and many other languages spoken in Central Europe. There were many challenges faced during the translation process, for example finding equivalent words. Compared to English, Hungarian is an agglutinative language (ICALTEFL n. d.). Therefore, special care was taken while translating the questionnaire from English to Hungarian to overcome language barriers.

Tab. 4: A brief description of the methodology design

\begin{tabular}{|c|c|c|}
\hline $\begin{array}{c}\text { Serial } \\
\text { Number }\end{array}$ & Description & Details \\
\hline 1. & Pilot Survey & $\begin{array}{l}\text { - } \quad \text { Previous pilot testing procedure by Paez (2010) was relied upon. } \\
\text { Included experts (from the USA, India, UAE, and Hungary) having } \\
\text { several years of experience administering and collecting data } \\
(n=3) \text {, professionals from hospitality industry }(n=3) \text {, disability } \\
\text { specialists }(n=2) \text { and linguists/certified translators }(n=2) \text {. }\end{array}$ \\
\hline 2. & $\begin{array}{l}\text { Validity of the } \\
\text { questionnaire }\end{array}$ & $\begin{array}{l}\text { - To examine the completeness and appropriateness of the } \\
\text { questionnaire, face, content and construct validity were adopted } \\
\text { in this study. }\end{array}$ \\
\hline 3. & Sample & $\begin{array}{ll} & \text { Non-probability convenience and snow ball sampling } \\
\end{array}$ \\
\hline 4. & Data collection & $\begin{array}{l}\text { - Secondary data: desk research (Electronic databases, print media, } \\
\text { census reports, corporate websites, annual reports, newsletters, } \\
\text { Govt. publications, etc.). } \\
\text { Primary data: Emails (personal and professional); Web-based } \\
\text { survey (Google forms); and Paper-and-pencil administration }\end{array}$ \\
\hline 5. & $\begin{array}{l}\text { Questionnaire } \\
\text { distribution }\end{array}$ & 859 \\
\hline 6. & Return & 212 \\
\hline 7. & Response Rate & $24.6 \%$ \\
\hline 8. & Used for Analysis & 174 \\
\hline
\end{tabular}

Source: Authors own work.

The official data collection was carried out in 2018 the city of Budapest, between February to May. Statistical analysis used Statistical Software for Social Science (SPSS) to address employer and business demographic data quantitatively.

Authors have had doubt in their minds regarding response rate prior distributing the questionnaires. There are many challenges faced by researchers to collect data through survey, especially on sensitive topics like disability studies which may create barrier for respondents in participating in such research. The respondents knowledge about the concept of disability (Fekete et al. 2015) or respondents general interest in research topic (Groves et al. 2004) may create general reluctance to participate in the study or respondents exit from the survey which eventually lowers the response rate. External 
surveys, no matter what distribution approach researcher choose, are expected to have an average $10-15 \%$ response rate (Fryrear 2015). Already published literature focusing on hospitality industry has also managed to share their response rate constraints. There is no fixed logic to explain what would be the response rate, but in general, the response rates are common, for example, response rate for employee surveys: $60-90 \%$; customer and member surveys: $5-40 \%$; general public: $1-20 \%$ (CIRT n. d.). A study by Cho et al. (2006), titled "Measuring the Impact of Human Resource Management Practices on Hospitality Firms' Performances" reported 36\% usable response rate (received 78 completed questionnaires out of 219 sample frame via mail survey option). A study conducted in Australia to examine the dimensions of service quality in the hospitality industry had only $15.5 \%$. In this study, a total of 1,000 questionnaires were distributed at five mid-luxury hotels in Australia, but 155 participants responses were collected (Wong et al. 1999).

\section{Results and Discussion}

Of the 174 respondents, there was not a big difference in gender participation, $50.6 \%$ male and $49.4 \%$ female respondents. $10.9 \%(n=19)$ participants had less than a year experience in hospitality industry, $17.2 \%(\mathrm{n}=30)$ had $1-5$ years of working experience, and $21.3 \%(n=37)$ had $6-10$ years of experience, $27.6 \%(n=48)$ had $11-15$ years of working experience, $13.2 \%(n=23)$ had $16-25$ years of working experience, and $9.8 \%$ $(n=17)$ over 25 years of working experience in hospitality industry. $16.7 \%$ of respondents had been in the current position between five and ten years and $7.5 \%$ were in the current position between eleven and fifteen years. While $4.6 \%$ of respondents were in their post between sixteen and twenty-five years, $2.5 \%$ of them were in their organization for 25 years and above. It was found that the highest percentage of respondents (50\%) belongs to the managerial cadre. Respondents from other management profiles, such as owners (15.5\%) and supervisors $(12.1 \%)$ constitute a higher percentage than from the area of other managerial designations. Beyond this, 137 respondents (53\%) were engaged independently owned properties, and 18 respondents (6\%) were in the franchised area and remaining (19 respondents) in chain organizations. The size of workforce within the respondent organizations: $60.9 \%$ of the total number of organizations surveyed employed a workforce of up to or less than 10 persons, $17.8 \%$ of the firms between $10-30$ employees, $8 \%$ of the firms between 31 - 49 employees, $3.4 \%$ of the firms between 50 - 99 employees, $6.3 \%$ of the firms between 100 - 249 employees, it was also found that $3.4 \%$ of respondent organizations had a workforce of over 250 persons.

On the issue of disability experiences of the respondents, 132 respondents reported experiences with people with disabilities, and only 1 respondent reported possessing some kind of a disability. Within the category of personal experiences with individuals with disabilities, 95 of respondents reported professional experience at work (coworkers possessing some kind of disability). The next group of respondent employing 
people with disabilities was found in a group of eleven departmental/job profiles comprising the supervisor, server, kitchen helper, cashier, custodian, maintenance, front desk, housekeeping, dish washer, manager, and others. Out of the total number of individuals with disabilities employed, it was observed that majority of employees with disabilities were actively involved in monotonous jobs or at the bottom of hierarchical structure, for example kitchen helpers $(n=63)$ and housekeeping staff $(n=33)$, and dish washers $(n=29)$. It can be also interpreted from this study that respondents currently working with employees with sensory, mental or physical disabilities. However, there was significantly disproportionate number reported for employees with physical disability $(n=57)$ in comparison to mental $(n=12)$ and sensory disability $(n=40)$.

Descriptive statistics, including frequencies, means, and standard deviations, were computed. Mean scores on the 17 statements (from part I) regarding a range of employment issues of employees with disabilities were calculated to identify employers' training attitude towards workers with disabilities. In general, employers who participated in this study had neutral attitude toward training people with disabilities with overall mean was 3.01 ( $\mathrm{SD}=0.34)$, scale of statements: scale: $1=$ strongly disagree, 2 = disagree, $3=$ neutral, $4=$ agree, $5=$ strongly agree .

For decades, the belief on range of skills demanded by employers have been mentioned in social sciences conceptual texts and too much attention given to technical and social skills, and less attributes on soft skills, which is an indispensable composite part of the employment in hospitality sector. Respondents expressed their understanding on the importance of providing training on social (48.3\% agreed) and communication (46.6\% agreed) skills for employees with disabilities, but had a different response on the importance of providing training on technical skills $(48.3 \%$ answered with neutral responses). Results reported differently by Paez (2010) on providing training to improve skills of PWD and also recorded highest mean for all three skills categories. One of the main barrier to the employment of people with disabilities is the lack of requisite skills and can have implications on the professional integration of PWD in the local work force. The hospitality industry provides numerous opportunities for people to break into the professional world, many positions are entry-level, and others demand much skill. The list of relevant skills is not exclusive, but includes skills such as knowledge in food service, hotel operations, food and beverage prep, maintenance, management, and more (Doyle 2019). The most important thing for employers to acknowledge that no one possesses all skills, individual with a disability is just as capable of being trained, groomed and efficient in accomplishing tasks as someone without a disability (Wiegand 2008).

A survey conducted by Cornell University involving private sector and federal human resource office holders to examine employer practices in response to the employment provisions of the Americans with Disabilities Act of 1990 (ADA) and related civil rights legislation (Bruyère 2000). It was published in the same document that $39 \%$ for private 
sector and $45 \%$ for federal respondents consented on lack of requisite skills and training strategies posing one of the largest continuing barriers to employment and advancement for persons with disabilities in the corporate world. Similarly, Huang \& Chen (2015) interviewed 12 Taiwanese employers to explore the experiences of employing individuals with disabilities stressed on the requirement of social, soft and technical skills to enter paid employment. Interviewees from private enterprise sector considered all these three skills relevant to perform tasks assigned to them and also as part of hiring guidelines to ascertain employee's ability to perform the job. Significantly, the issue of addressing and acknowledging training employees with disabilities in hospitality sector is another concern for managers. Can managers use/would use different training methods and topics for employees with disabilities, depending on disability and the job? Do managers need to develop and implement individualized training programs to address and accommodate each employee's disability? Would providing diverse training options (depending on the type and severity of disabilities, and job tasks) to individuals with disabilities incur extra cost for employers?

$57.5 \%$ of respondents disagreed (either strongly or otherwise) with the statement, depending on the job, it costs/would cost me more to train employees with disabilities, $17.2 \%$ agreed or strongly agreed and $25.3 \%$ neither agreed nor disagreed (neutral). Similarly, $40.8 \%$ of the respondents disagreed or strongly disagreed, overall $59.2 \%$ of the respondents were either uncertain, agreed or strongly agreed with the statement, depending on the disability, it costs/would cost me more to train employees with disabilities. 66 individuals (37.9\%) categorized themselves as respondents who disagree with the statement, it is too costly to give additional training to employees with disabilities, indicating the fact that employers have an open mind in providing training opportunities to EWD. An interesting trend noticed here in this study were the wide range of responses (either agree or disagree) reported in majority of responses and it can be interpreted as employers are unsure regarding the issues on providing training and skill development avenues to the employees with disabilities. Of the employers who gave information related to training methods they had provided, 72 out of $174(41.4 \%)$ agreed use different training methods for employees with disabilities. Another group of respondents, 64 individuals (36.8\%) also agreed train/would train all employees using the same methods regardless of their disability. 
Tab. 5: Respondents Attitudes towards Training People with Disabilities in Hospitality Sector.

\begin{tabular}{|c|c|c|}
\hline Statement & $\begin{array}{l}\text { Mean } \\
\text { (M) }\end{array}$ & $\begin{array}{c}\text { Standard } \\
\text { Deviation } \\
\text { (SD) }\end{array}$ \\
\hline Providing training on technical skills for employees with disabilities is important. & 3.32 & 0.812 \\
\hline Providing training on social skills for employees with disabilities is important. & 3.32 & 0.802 \\
\hline $\begin{array}{l}\text { Providing training on communication skills for employees with disabilities is } \\
\text { important }\end{array}$ & 3.45 & 0.885 \\
\hline I use/would use different training methods for employees with disabilities. & 3.36 & 0.814 \\
\hline $\begin{array}{l}\text { I train/would train on different topics if a employee with disability has a specific } \\
\text { disability. }\end{array}$ & 3.47 & 0.839 \\
\hline I train/would train on different topics if an employee with disability has a certain job. & 3.53 & 0.880 \\
\hline $\begin{array}{l}\text { I train/would train all employees using the same methods whether they are disabled } \\
\text { or not. }\end{array}$ & 3.02 & 0.991 \\
\hline $\begin{array}{l}\text { Depending on the job, I spend/would spend more time training employees with } \\
\text { disabilities than employees without disabilities. }\end{array}$ & 2.80 & 0.902 \\
\hline $\begin{array}{l}\text { Depending on the disability, I spend/would spend more time training employees with } \\
\text { disabilities than employees without disabilities. }\end{array}$ & 2.61 & 0.968 \\
\hline $\begin{array}{l}\text { I use/would use the same training tools for employees with disabilities as those } \\
\text { without disabilities. }\end{array}$ & 2.98 & 1.054 \\
\hline $\begin{array}{l}\text { I do not believe employees with disabilities need to be trained differently than } \\
\text { employees without disabilities. }\end{array}$ & 3.02 & 1.032 \\
\hline $\begin{array}{l}\text { Even after training, employees with disabilities need special attention from } \\
\text { supervisors. }\end{array}$ & 2.79 & 0.995 \\
\hline $\begin{array}{l}\text { Depending on the job, employees with disabilities are harder to train than employees } \\
\text { without disabilities. }\end{array}$ & 2.91 & 0.935 \\
\hline $\begin{array}{l}\text { Depending on the disability, employees with disabilities are harder to train than } \\
\text { employees without disabilities. }\end{array}$ & 2.68 & 0.894 \\
\hline I feel it is too costly to give additional training to employees with disabilities. & 2.54 & 1.159 \\
\hline $\begin{array}{l}\text { Depending on the job, it costs/would cost me more to train employees with } \\
\text { disabilities. }\end{array}$ & 2.55 & 1.075 \\
\hline $\begin{array}{l}\text { Depending on the disability, it costs/would cost me more to train employees with } \\
\text { disabilities. }\end{array}$ & 2.74 & 1.035 \\
\hline
\end{tabular}

Source: Authors own work based on SPSS results.

This research addressed training concerns across a variety of corporate domains associated with training, for example focus on different types of skills development strategies, selection of training methods and topics depending on the type of disability/job specification and finally, cost concerns of employers. The employers need to have a flexible approach on addressing training related issues pertaining to employees with disabilities, regardless of hierarchy of disabilities and job specifications. The different types and grades of disabilities can require different teaching methods for the same skill or task (Groschl 2012).

A survey by K.A. Dixon with Doug Kruse, and Carl E. Van Hornin in 2003 documented in their report that lack of skills and experience, and the lack of training programs are 
greatest barriers for people with disabilities to integrate into the labor market. Besides the cost of accommodation, the survey which incorporated completed 501 interviews in the USA divulgate that employers are divided on the cost and importance of training. A manager in a study which explored the experiences of major Canadian hotel organizations and employment agencies pointed that it costs more to the organization to train EWD then their counterparts without disabilities (Groschl 2007). Findings of this qualitative semi-structured interviews article which included 6 important tourist destinations in Canada, documented that employees with disabilities are less productive as compared to co-workers without disabilities, needs constant monitoring and take longer to be trained.

It has been pointed out in the international literature that job specifications and type/severity of disability possessed by an employee does influence employers perception towards integration EWD at the place of work. Globally, employers posit mental illness as compared to other types of disabilities, as a major employment issue and have their concerns regarding individuals with disabilities entering paid employment. Individuals with mental disability are more negatively stereotyped as compared to other disabilities, which may lead to discriminatory behavior towards individuals with disabilities in finding employment. Some theoretically and empirically based literature provides some sort of relationship between disability hierarchy and training/employment outcomes. A retrospective study conducted in Taiwan by Jang et al. (2014) to evaluate factors affecting employment outcomes for people with disabilities found that individuals with visual disabilities (86.6\%)reported higher rate of successful employment outcomes after receiving Disability Employment Services (DES), and those with the emotional disabilities had the lowest (50.7\%). The cost-related impact on enterprises in terms of money, time and productivity is one key concern faced by employers. The cost of additional supervision and training to support a person with disability, especially employing people with intellectual disabilities are one of the few findings of National Centre for Vocational Education Research (NCVER) report (Waterhouse et. al 2010). In this report, an employer in a focus group shared his experiences in providing training to individuals with intellectual disabilities. He stated that such individuals demand intense supervision despite of providing customized training schedule and same employer was still not confident of them working without any supervision, even after giving them ample learning opportunities. According to Chi \& Qu, cited in Houtenville and Kalargyrou (2015 p. 170), restaurant employers were found to have more positive attitudes toward employees with sensory impairment and physical disabilities than toward employees with mental disabilities. On the contrary, an interviewee in study of K. Donnelly, K. and J. Joseph (2012) stated that the performance employees with physical or cognitive disabilities at The Murray Hill Inn and Suites (a 76-room property) was same (or higher) level as the rest of the employees following adequate training. 
Importantly, benefits of providing training to employees can be categorized into two categories: "micro or individual level approach may allow companies to tailor their training programs to allow the maximum benefit for individuals, and in turn, the firm. From a societal perspective, training and placement may increase the economic independence of disabled individuals and reduce their financial dependence on the system" (Stahl, 2015 p.27). Groschl (2012) in his article documented that employers can practically convert costs incurred in training individuals with disabilities into long term investments as it believed that such employees are loyal and committed to their employers for longer duration. This case study was conducted in five different hotels (within Germany's Embrace hotel association) where more than 60\% people with disabilities including individuals with severe disabilities were reported to professionally integrate into the workforce. Using 359 firms with over 12 years of longitudinal firm-level profit data, Kim and Ployhart (2014), highlighted in their study that internal training interactively influence firm profit growth, may be used strategically to weather economic uncertainty (recession effects), and corporate with efficient and well trained staff will outperform competitors throughout all pre- and post recessionary periods. Moreover, complexity of disabilities may be considered financial burden on companies, and employers prejudiced perception regarding EWD lacking the technical knowledge, skills and abilities can be dismissed by providing proper training and enhancing their jobs skills to enter and sustain in paid employment (Stahl 2015). All Employers do not have consensus on the economic benefits of employing individuals with disabilities. An employer who worked with few individuals with disabilities in his medium-sized furniture manufacturing enterprise in Australia talked about his social conscience as an employer, but stated that there is 'definitely not an economic benefit for the employer it simply doesn't add up'. (Waterhouse et al. 2010 p. 19).

Employees with disabilities often require some sort of job accommodations (e.g., specialized equipment, facility modifications, adjustments to work schedules or job duties) to perform their professional tasks. The statement with the highest mean score was the one that related to statement, I make/would make reasonable accommodations for employees with disabilities, with mean $3.68(\mathrm{SD}=0.956)$. This was another research objective of this study to find out employers intentions on providing reasonable accommodation to hire and retain EWD at the place of work. 9.8\% of respondents disagreed or strongly disagreed, and $60.3 \%$ agreed or strongly agreed with that statement. Thus, hundred and five respondents believe in providing additional support to employees with disabilities, if required, would enhance professional effectiveness in the place of work. To provide all inclusive work place, employers worldwide are legally required to make reasonable accommodations, such as making recruitment and selection procedures accessible, adapting the working environment, modifying working times, and providing assistive technologies (WHO 2011). The general notion behind providing reasonable accommodation to individual with disabilities at the place of work is to confirm that the employer has legally acknowledged disability of employees, provides reasonable and necessary accommodation for employees to perform their 
official tasks effectively and efficiently, and the job related support provided at minimum costs (Telwatte et al. 2017). Internationally, several authors have probed the factors which influences behavior of employers towards providing reasonable accommodation: knowledge of disability legislation (Brohan et al. 2010); attitudes of managers towards employee with disabilities (Telwatte et al., 2017), and personal and professional contact with individuals with disabilities (Telwatte et al. 2017; Scherbaum et al., 2005) , and financial burden concerns ( Stahl, 2015; Kaye, Jans and Jones 2011; Donnelly and Joseph 2012)

The Job Accommodation Network (JAN) is a service of the Office of Disability Employment Policy of the U.S. Department of Labor conducted interviews in the USA to evaluate the impact of workplace accommodation (Loy 2017). It was reported that workplace accommodations not only are of low cost (cost absolutely nothing to make, while the rest typically cost only $\$ 500$ ), but also have many benefits for firms in longer term. In another survey report which highlighted the challenges of work place accommodations from employers perspectives and policy strategies needed to increase workplace accessibility for all employees and job prospects (Dixon et al. 2003). Majority of respondents (50\%) in this report confirmed that the cost of making changes were less costly, but $14 \%$ of them expressed their concern on accommodation implementation being costly.

It also important for employers to acknowledge that developing well-designed accommodations will not only benefit employees with disabilities but such structural and technologically upgraded facilities will also attract customers with disabilities. Poria et al. (2011) interviewed 45 participants (20 used wheelchairs; ten were dependent on crutches; and 15 were blind) in their exploratory study focusing on the tourism experiences of people with disabilities. To encourage employers to consider the option of providing reasonable accommodations, states have introduced many financial supports, such as tax incentives that would eventually help employers to cover additional costs that would have incurred otherwise (WHO 2011).

Addressing the third objective of the study, respondents were asked if they perceive that aesthetic and self-presentation skills are pre-requisite requirement to apply for a position in hospitality industry; $39.7 \%$ agreed that it is important for hospitality industry, $37.9 \%$ answered with neutral response, and $10.9 \%$ agreed. It is usually assumed that customers immediately make judgments about the hotel or restaurant as soon as they enter. Front line employees make an impact on customers expectations as customers have many choices to patronize. To ensure welcoming environment, customer loyalty and build brand image, service managers will presumably opt for 'able-bodied' aspirants when hiring new employee/s. Likewise, Nickson et al. (2005) study based on the responses to a structured questionnaire from employers in the retail and hospitality industries in Glasgow, suggested that in their study that employers are 
not generally looking for "hard" technical skills in their front-line employees, but rather "soft" skills (importantly "right" appearance).

Hui et al. (2017) in their mixed method study which was conducted in Hong Kong highlighted that PWD could face professional barriers to enter hospitality sector as they might not fit in the traditional concept of physical attractiveness with high selfpresentation skills. Similarly, a study conducted in Turkey, where experts and professionals working in the fields of disability and hospitality sector participated to evaluate potential effects of employing PWD on management and organizational performance (Bengisua and Balta 2011). One of the important findings of this study was recruitment of employees should be based on merit, job suitability and individual capability, regardless of the presence or degree of disability. In this report it was mentioned that aspirants with orthopedic and other disabilities might not be considered for front line job profiles as employers emphasis is more on abilities of emotional display, aesthetics and physical appearance.

There are many possible ways for employers in service oriented industry to attract customers, gain market share and build customer loyalty. Corporate social strategy (CSR) can represent a potential input to differentiation strategy, and corporates can differentiate themselves effectively from rest of the competitors (Boehe and Cruz 2010). Kuo and Kalargyrou (2014) in their single-factor experimental design study found that consumers demonstrated a moderately positive purchase intention for a restaurant that employed individual with disabilities. A case study conducted in five Embrace member hotels where guests with and without disabilities shared their perception and confirmed that physical attributes of EWD did not interfere in their day to day performance, and guests reported no negative experiences (Groschl 2012).

\section{Conclusion}

The article aimed to provide more detailed explanation and illustrations on the concept of inclusive corporate training and skill development avenues, and also as a starting point to exploring wider possibilities to promote the employment of people with disabilities in Hungarian context.

Overall, the analysis of survey data collected in 2018 from the city of Budapest, addresses several important questions into how employers perceive about providing training and skills development opportunities for people with disabilities and how they conceptually process accommodation requests. On the one hand, employers have expressed for the most part, neutral attitudes toward training employees with disabilities in the hospitality sector in Hungary, but on the other hand, 105 respondents reported greater willingness to grant reasonable accommodation.

While the current study examined training and skill development indicators in respect to employability of individuals with disabilities, it also has investigated the importance 
of aesthetic labor in hospitality industry. Empirically proven in this study that majority of respondents (69) agree to the statement, aesthetic and self-presentation skills are prerequisite requirement to apply for a position in hospitality industry, and this implies that this could the diminish chances of professional integration of people with disabilities in the hospitality industry. Authors feel that the critical investigation of aesthetisation paradigm secure conceptual grip in international literature, concerning employees who do not fit into 'embodied dimensions' of aesthetic labor. It may be beneficial for employers to review and address this aesthetic related concern in a more positively manner to influence corporate culture.

Every research is limited by many personal, professional, theoretical, methodological and practical factors, and this article is not an exception. There is a possibility that employers (respondents) understanding and unfamiliarity with few definitions and key words, for instance aesthetic and self presentation skills, might have lead to deviation from realistic results. Though definitions of important terms were addressed in each section of the questionnaire, but respondents might have missed them while glancing through the questionnaire.

The findings of this study are inadequate to be generalized to the whole population of employers in hospitality sector who are working with individuals with disabilities. Since this study did not include all types of registered categories of disability, the generalization of this research should be made vigilantly. Another concern to be addressed, due to the nature of the study, is the issue that respondents may have expressed politically correct and socially desirable feedback (McCaughey and Strohmer 2005), instead of displaying realistic attitudes toward individuals with disabilities in the place of work.

Only employers from hospitality industry were included in this study, but there is a possibility that different display of attitudes would be observed from respondents from different sector. Similarly, different types of disability if included in this study might have resulted in far more positive findings, but this is an empirical question that would be addressed in forthcoming research papers. Despite few limitations mentioned in this study and based on results discussed above, few recommendations offered for different stakeholders. Disability research is a relatively new field in hospitality sector in Hungary, the data collection methods can be expanded to other geographical locations within Hungary, specifically Balaton Lake. Authors feel that this step in data collection would allow for optimum response rates and would eventually help to assess the impact on the labor market participation of people with disabilities. Additional research needed regarding employers reactions on aesthetic labor as very little research has addressed this issue in Hungary. Qualitative methods, for example focus group and interviews with employers in Hungary will help to better understand their perspectives on the importance of aesthetic and self presentations in the hospitality sector. 


\section{References}

ALDERMAN, L. and SANTORA, M., 2019. Hungary's Nationalist Policies Have Created a Labor Shortage. The Fix Isn't Helping. The New York Times Company. [accessed: 2019-05-06] Available at: https://www.nytimes.com/2019/05/03/business/hungaryslave-law.html.

BOEHE, D.M. and CRUZ, L.B., 2010. "Corporate social responsibility, product differentiation strategy and export performance". Journal of Business Ethics. 91(2), 325346.

BENGISU, M. and BALTA, S., 2011. Employment of the Workforce with Disabilities in the Hospitality Industry. Journal of Sustainable Tourism. 19(1), 35-57.

BROHAN, E., HENDERSON, C., LITTLE, K. and THORNICROFT, G., 2010. Employees with Mental Health Problems: Survey of UK employers' Knowledge, Attitudes and Workplace Practices. Epidemiologia e psichiatria sociale. 19(04), 326-332.

BRUYERE, S., 2000. Disability Employment Policies and Practices in Private and Federal Sector Oganizations. Ithaca: Cornell University, Program on Employment and Disability. [accessed: 2017.03.13].

Available: http://digitalcommons.ilr.cornell.edu/cgi/viewcontent.cgi?article=1062\&context=edico $\underline{\text { lect. }}$

CHI, C. G.-Q. and QU. H., 2003. Integrating Persons with Disabilities into the Workforce: A Study on Employment of People With Disabilities jn Foodservice Industry. International Journal of Hospitality \& Tourism Administration. 4(4), 59-83.

CIRT, n. d. Survey Response Rates. Grand Canyon University, Center for Innovation in Research and Teaching. [accessed: 2018.04.09]. Available at: https://cirt.gcu.edu/research/developmentresources/research_ready/designing_surve ys/response_rates.

CHO. S., WOODS R. H., JANG, S. and ERDEM, M., 2006. Measuring the Impact of Human Resource Management Practices on Hospitality Firms'. International Journal of Hospitality Managemen. 25(2), 262-277.

DIXON, K. A., KRUSE, D. and VAN HORN, C. E., 2003. Restricted access: A survey of employers about people with disabilities and lowering barriers to work. [accessed: 2019.0: 6.03] Available at https://smlr.rutgers.edu/sites/default/files/documents/Heldrich\%20disability\%20sur vey\%20report.pdf.

DONNELLY, K. and JOSEPH, J. 2012. Disability Employment in the Hospitality Industry: Human Resources Considerations. Cornell HR Review. [accessed: 2018.05.01]. Available at Cornell University, ILR School site: http://digitalcommons.ilr.cornell.edu/chrr/27 
DOYLE, A., 2019. Important Hospitality Skills for Resumes \& Cover Letters. Terms to Include to Help Bolster Your Resume. [accessed: 2019.05.09] Available at: https://www.thebalancecareers.com/hospitality-industry-skills-2062407

EUROSTAT, 2014. Situation of People with Disabilities in the EU. Eurostat News Release.

Retrieved from: [accessed: 2018.01.04]. Available at: http://ec.europa.eu/eurostat/documents/2995521/6181592/3-02122014-BPEN.pdf/aefdf716-f420-448f-8cba-893e90e6b460

FEKETE, C., SEGERER, W., GEMPERLI, A. and BRINKHOF, M. W., 2015. Participation Rates, Response Bias and Response Behaviours in the Community Survey of the Swiss Spinal Cord Injury Cohort Study (SwiSCI). BMC Medical Research Methodology. 15(80).

FRYREAR, A., 2015. What's a Good Survey Response Rate? [accessed: 2018.04.09]. Available at: https://www.surveygizmo.com/resources/blog/survey-response-rates/

GROSCHL, S., 2012. Presumed Incapable: Exploring the Validity of Negative Judgments about Persons with Disabilities and Their Employability in Hotel Operations. Focus on Human Resources. Cornell Hospitality Quarterly, 54(2), 114-123. DOI: $10.1177 / 1938965512453082$.

GROSCHL, S., 2007. An Exploration of HR Policies and Practices Affecting the Integration of Persons with Disabilities in the Hotel Industry in Major Canadian Tourism Destinations. Hospitality Management, 26, 666-686.

GROVES, R. M., PRESSER, S. and DIPKO, S., 2004. The Role of Topic Interest in Survey Participation Decisions. Public Opinion Quarterly. 68(1), 2-31.

HOUTENVILlE, A. and KALARGYROU, V., 2015. Employers' Perspectives about Employing People with Disabilities: A Comparative Study across Industries. Cornell Hospitality Quarterly, 56(2), 168-179.

HUANG, I. and CHEN, R. K., 2015. Employing People with Disabilities in the Taiwanese Workplace: Employers' Perceptions and Considerations. Rehabilitation Counseling Bulletin. 59(1), 43-54.

HUI, R. T., TSUI, B. and TAVITIYAMAN, P., 2017. Disability Employment in Chinese Context: A Case of Position Differences in the Employees' Perception in an Europeanbrand Hotel in Hong Kong. ANZAM conference. [accessed: 2018.05.03]. Available at : https://www.anzam.org/wp-content/uploads/2018/02/ANZAM-2017-364.pdf

ICALTEFL, n. d. Hungarian vs. English. In Foreign Language vs. English. [accessed: 2018.02.08]. Available at: http://www.icaltefl.com/hungarian-vs-english

JANG, Y., WANG, Y. and LIN, M., 2014. Factors Affecting Employment Outcomes for People with Disabilities Who Received Disability Employment Services in Taiwan. Journal of Occupational Rehabilitation. 24(1), 11-21.

KAYE, H. S., Jans, L. H. and Jones, E. C., 2011. Why don't employers hire and retain workers with disabilities? Journal of Occupational Rehabilitation, 21(4), 526-536. 
KIM, Y. and PLOYHART, R.E., 2014. The Effects of Staffing and Training on Firm Productivity and Profit Growth Before, During, and After the Great Recession. Journal of Applied Psychology, 99(3), 361-389.

KOTHARI, C. R., 2004. Research Methodology: Methods \&Techniques. Second Revised Edition. New Age International (P) Ltd., Publishers. ISBN (13): 978-81-224-2488-1.

KSH, 2017. Hungary 2016. Hungarian Central Statistical Office 2017. [accessed: 2018.06.02]. Available at: https://www.ksh.hu/docs/hun/xftp/idoszaki/mo/hungary2016.pdf

KSH, 2016. Hungarian Central Statistical office. [accessed: 2018.01.04] Available at: https://www.ksh.hu/stadat_infra_9_2

KSH, 2011 a. Fogyatékossággal élők, 11. ((Hungarian Central Statistical Office, 2011 Census, 11. People with disabilities; page number 13). Accessed: 2019.07.29]. Available at: http://www.ksh.hu/docs/hun/xftp/idoszaki/nepsz2011/nepsz 11 2011.pdf

KSH, 2011 b. Census 2011 Data about Employed People with Disabilities (Age and Indusrty). [accessed: 2018.08.13]. Available at: http://www.ksh.hu/nepszamlalas/docs/tablak/fogyatekossag/11 $020209 . x \mathrm{ls}$

KUO, P. and KALARGYROU, V., 2014. Consumers' Perspectives on Service Staff with Disabilities in the Hospitality Industry. International Journal of Contemporary Hospitality Management. 26(2), 164-182.

LOY, L., 2017. Workplace Accommodations: Low Cost, High Impact. Job Accommodation Network. U.S. Department of Labor's Office of Disability Employment Policy.

MCCAUGHEY, T. J. and STROHMER, D. C., 2005. Prototypes as an Indirect Measure of Attitudes toward Disability Groups. Rehabilitation Counseling Bulletin, 48(2), 89-99.

NICKSON, D., WARHURST, C. and DUTTON, E. 2005. The Importance Of Attitude And Appearance In The Service Encounter In Retail And Hospitality. Managing Service Quality, 15(2), 195-208.

PAEZ, P., 2010.Training Methods and Topics for Hospitality Employees with Disabilities: Managers' Attitudes and Perceived Knowledge. PhD Thesis. [accesses: 2018.02.25]. Available at from https://lib.dr.iastate.edu/cgi/viewcontent.cgi?referer=https://www.google.hu/\&httpsr edir $=1 \&$ article $=2461 \&$ context $=$ etd

PORIA, Y., REICHEL, A. and BRANDT, Y., 2011. "Dimensions of Hotel Experience of People with Disabilities: An Exploratory Study", International Journal of Contemporary Hospitality Management, 23(5), 571-591.

RHS, 2018. Disability Information in Hungary. RHS 2011 fall 2018. [accessed: 2018.07.30]. Available at: https://sites.psu.edu/rhs100fa18001/2018/10/05/disability-information-in-hungary/ 
SCHERBAUM, C. A., SCHERBAUM, K. L. and POPOVICH, P. M., 2005. Predicting JobRelated Expectancies and Affective Reactions to Employees with Disabilities from Previous Work Experiences. Journal of Applied Social Psychology, 35(5), 889-904.

SEKARAN, U., 2003. Research Methods for Business. A Skill Building Approach. 4th Edition. John Wiley \& Sons, Inc. USA. ISBN 0-471-20366-1.

STAHL, J., 2015. Disability Status, Disability Type, and Training as Predictors of Job Placement. PhD Dissertation. Clemson University.

TELWATTE, A., ANGLiM, J., WYNTON, S. K. A. and MOULDING, R., 2017. Workplace Accommodations for Employees with Disabilities: A Multilevel Model of Employer Decision-Making. Rehabilitation Psychology. Advanced Online Access. http://dx.doi.org/10.1037/rep0000120

WATERHOUSE, P., KIMBERLEY, H., JONAS, P. and GLOVER, J., 2010. What would it take? Employer Perspectives on Employing People with a Disability. [accessed: 2018.05.03]. Available at: http://www.ncver.edu.au/publications/2219.html

WHO (2011). World Report on Disability: Summary. World Health Organisation.

WIEGAND, A. B., 2008. Possible Factors Influencing Hiring Decisions For Physically Disabled Applicants. 6th Annual Western Pennsylvania Undergraduate Psychology Conference. Erie, PA. [accessed: 2018.02.03]. Available at: http://www.drspeg.com/research/2008/hiringbias.pdf

WONG, A.O.M., DEAN, A. M. and WHITE, C. J., 1999. "Analysing Service Quality in the Hospitality Industry”. Managing Service Quality. 9(2), 136-143.

\section{Contact address of the author(s):}

Dr. Ambuj Sharma, Ph.D. Department of Business Economics and Management, Faculty of Economics and Social Sciences, Szent István University, Gödöllő, H-2100 Páter K. u. 1., e-mail: Sharma.Ambuj@hallgato.szie.hu

Dr. Martin Zsarnoczky, PhD. Kodolanyi Janos University of Applied Science, Frangepán Str. 50-56, Budapest 1139, Hungary, email: martin.zsarnoczky@casadelmusica.hu

Dr. habil Anna Dunay, Ph.D., Department of Business Economics and Management, Faculty of Economics and Social Sciences, Szent István University, Gödöllő, H-2100 Páter K. u. 1., e-mail: Dunay.Anna@gtk.szie.hu 